\title{
Economic Counseling Psychology for Management Economic Crisis
}

\author{
Elfi Mu’awanah \\ IAIN Tulungagung, East Java, Indonesia
}

\begin{abstract}
In the economic world of the economic class down there are some challenges in economic life that is the ability to survive in a mediocre economy, defend themselves against the work they have lived so far, mental reinforcement when unable to buy anything, self-surrender to the economic destiny they endured. is the economic counseling of the Quran, is one of the approaches given to the poor who face problems such as removing "I'm confused, I want to kill myself, just die if I keep this up". Through the verses of the Koran given to the poor primarily, being able to reduce the mental pressure of suicidal ideation and build resilience in the face of life's problems.
\end{abstract}

Keywords: counseling for facing economic problem, economic counseling of the Quran, majlis ta'lim

\section{Introduction}

Economic activities that generate income in the family are an important asset in living a family life and, society and also more important to the results of economic results that a person is able to have the ability of self-management to the needs and ability to accept economic conditions. The extent to which a person is supposed to prioritize the optimal economic gain in his life, but when subsequently the economic work derived from a person far from expectations, it should not fade the belief that every human being is required to try but the problem of results is determined by God. In the economic work effort several studies have conducted research and provided some economic solutions, which in the end is expected that each individual can understand the pattern of economic work itself and receive economic capabilities resulting from economic work.

In fact people who suffer from poverty need to get attention and how to keep power in the condition of the ability of resources to meet the economic needs and the ability to accept economic conditions while living life is more important so that people remain happy to live their lives, not looking for economic roads that contrary to the norm of life. Several researches have been done to increase the income of the society's poorest society as the poor. Several studies are concerned about the economy of the poor and making economic improvements. Here are some research results that people can choose to increase income in the family economy. Economic conditions in the poor category not only occur in Indonesia but also in LAN countries. Some research results that try to lift and help overcome the economic conditions are as follows.

A study that sees the implications of the equilibrium assumption regarding the development of a market

Acknowledgment: Thank for Kemenag RI at ISFI Program on December 2018, and ISESS Okinawa Japan, 2018. Elfi Mu'awanah, Associate Professor, Guidance and Counselling, IAIN Tulungagung, East Java, Indonesia. 
economy replaces the social relations of human capital. The strength of economic clustering and human capital has a correlation between population density and income which is a stronger relationship both. While the framework of the capital framework standards is much steady in the city's less developed data, the productivity and growth of urban growth in some areas is crucial to the economic strength of the country. From the research data found that urban development, productivity, and urbanization growth in both middle to upper economic class countries and lower middle economic countries like Brazil, China, India, and the United States will affect the economy as research conducted by Chauvin, Glaser, Ma, and Tobio (2017, pp. 17-49).

The economy and externalities of human capital appear to be cooperative, and so in four in a country there is relevance between the livelihood of the living and the income received the U.S. territory, which is also stronger, though precisely measured, in China and India. Thus to increase happiness by still receiving no matter how much economic income earning is important to do because the key is the power of accepting economic conditions and the acceptance of this self-economic condition is a form of human spiritual closeness with God.

\section{Literature Review}

Silvestre and Neto (2014, pp. 1-9) are through the concept of mining and manufacturing companies. This study offers three major contributions to research on production cleaners, sustainability, and innovation. First, we claim that a cleaner production approach cannot create sustainable mining areas, but it is a step toward sustainability. Secondly, we argue that technology does not represent a complete solution to the problem of corporate sustainability. Third, we claim that commercial firms can face a "managerial trap" if they seek to improve the performance of sustainability solely through the adoption of innovative production cleaners. Information about the lives people who have citizens below the poverty line who need attention are capabilities in three cities in Mexico through the research of Avilés, Larghi, and Aguayo (2016, pp. 1-12) who seek to represent the debate about the adoption of information technology (ICT) in reducing poverty how the poor go in, share, and use ICT in their daily lives - when we are in the life of the poor formation. The author identified the challenges and challenges faced in the adoption of ICT in three rural communities with varying degrees of ionization and marginal relations in Mexico. It may have an impact on the poverty situation. With ongoing training through his role in the information diary, the less likely it is to join in developing new skills, to engage in new practices and find ways to apply them. A specification that does not get attention deliberator is the productive role of many families who become members of the family; we found that adoption of ICTs implements information retrieval patterns and increases in informational capabilities and the presence of low-income commercial units may increase poor economic income.

The theory of distribution of economic growth that generates income for the improvement of welfare for the poor is an important study that needs to be done especially in the framework of increasing the income of the poor by Harmacek, Syrovatka, and Duskova (2016, pp. 1-26). For developing countries the matter of concern is how to increase the income of the lower middle class. The target is that they will increase their economic work and become prosperous. Moving economic status to shifting towards better than before, will be able to increase happiness in people's lives. Whatever the economy is high, prosperity and happiness will be high too. However often inequality always becomes a high wall gap between rich economic conditions and poor economic conditions. If possible, it is necessary to work together to build a new lifestyle and reduce inequality. It's just that unfortunately the formulation to break inequality will always be difficult to solve. Even famine often occurs between upper and lower economic communities. Martinez (2013, pp. 1-3), in a poor economy class 
society there is equality in the use of natural resources. If you have mining, energy processors, land cases, often the poor people farmers always lose because of the lack of experts in the field of natural resources. Because it is necessary to develop natural resources supported by human resources so as not to miss their income economy. of developing countries as written by Chyi and Hwan (2011, pp. 374-381) is carried out with one way to the steady-state low-income and the other toward a steady-state high-income. With pro-market infrastructure and institutions supporting low transaction costs, market access, and legal security for businesses, markets are more likely to build and expand such as asphalted roads, water and electricity supplies, establishment of property and contract law rights, etc. When these market producers' infrastructure and institutions are available for one country, there will be a rich variety and number of manufactured goods for home-holdings to buy from the market.

The transformation of urban land for a pro-poor economy is a feasible effort for the economic hatching of the poor as Benjamin (2004, pp. 177-187). Transforms land into an arrangement for grouping the local economy can be an important foundation in determining regulations that benefit the poor. Institutional politics also needs to reduce regulations that can provide opportunities for increasing the economy of the poor Grouping of seemingly "slum-like" land seems to be very productive and produces jobs. This is the stage in which the poor are the central actors who accelerate complex alliances across ethnic and class lines to shape the city for their own sake. The transformation of land into an arrangement to classify the local economy can be an important foundation in the policy of poverty. Institutional improvement needs to be truly in favor of the poor shelves so as to provide opportunities for increasing their welfare. The attractiveness of the market in the economically developed supermarkets and poor consumers of Vietnam in the research of Figuié and Moustier (2009, pp. 210-217) the emergence of an idea in Vietnam to change the level of the economy through a supermarket model for food distribution and sales is very helpful in the process of improving people's welfare. Economic risk management, accompanied by a clear market analysis in Hanoi, shows that poor consumers need formal outlets that have easy access to business development through low interest credit. In the distribution of sales in supermarkets, the poor economy still feels that they are only consumers and cannot control supermarket management. Poor people are still accustomed to buying goods not to buy goods as capital for their business development. It seems that there are still supermarket owners and consumers of poor communities. The master plan and in Colombia there are efforts to change poor ecosystems into rich ecosystems a study by Sliwa (2017, pp. 1-12). The redesign and creative changes of residential the opening of employment and income fields for the community is the most important and needed by the poor. land use as a field of business opportunities to increase their income and social capital and economic capital need to be considered whether that strengthens the work motivation of the poor according to Sok (2017, pp. 1-8) examines the development of unfavorable growth and income inequality of poverty. From the findings of the study, publicity is proven capable of generating brand economic ventures. Poverty is caused due to unequal distribution, the position of infrastructure does not support besides the competency factor and job share opportunities for the poor. The undertaking is not achieved without predicting future preparations made to realize the improvement of the agricultural business sector, as well as the economic development sector, investment intervention in infrastructure optimization, the increase in the ability of the lower classes along with the ability to understand demographic characteristics as well. Unfortunately people who are skilled and reliable actually choose to live in the city rather than in the village. It seems that the Cambodian population has not been able to transform a village that is thick with poverty into capital for developing a vital economic endeavor for the village 
community. This has had an effect on low wages and poverty in rural areas. For Cambodia the most important thing is that the survival of their families requires a significant distribution of work, employment opportunities and wages to achieve economic development in the countryside. Third, the availability of market opportunities, high wages for the distribution of livelihoods are expected to be able to live and carry out economic activities to sustain life even between the agricultural sector and other sectors are expected to support each other so as to enhance economic development as well as understanding capital demographic characteristics. Alignments in urban areas as economic development need to be transferred to rural communities.

Schwartz, Tutusaus, and Savelli (2017, pp. 1-10) found the need for Kenya requires the distribution of water in the poor economic communities that live there, which can also be used as an effort to increase economic production. Kenya's water utilization faces the challenge of balancing commercial financial interests through a social goal that reflects the ultimate goal of sociological goals and improves and reflects a decrease in the utility of the core services of provision of responsibilities and increasing low-income to higher levels. By identifying these issues, the capacity of organizational intermediaries, social justice, and service modalities not to be different in understanding differences. As for the purpose of research is to use and this research emphasizes the interests of consumers, the balance of differentiation. Cooperation is also in advocating advocacy for service differentiation models, including donation officials in defending the poor and the use of water for fisheries businesses equipped with business capital in accordance with economic business needs. Holden and Ghebru (2016, pp. 21-28) Examine land tenure, property security and food security reform in a poor agricultural economy. The paper that was made was containing the suitability between the basic theory and literature for the relationship between infrastructure securities with food. The study also discusses the relationship between theory and land ownership reform. the study also discusses the need for social conflict to trigger insecurity at work as well as the food crisis in parts of Africa and the Middle East internationally that are rapidly developing migrants who are below the poverty line but able to increase their wealth and security livelihoods. If high population density contributes to economic difficulties in agrarian society. The need for employment creation is important for social life. There is a link between property security and food security, so it needs maximum efforts to be available for the poor.

Suárez (2016, pp. 1-11) examines the difficulties in mobile money (as well as car payment) so far unevenly by country. In Kenya more than $50 \%$ of populations use electronic payment platforms, in Mexico the proportion is almost over $2 \%$. The actors and politicians around diffusion are the key to success. At first, the arrest rules highlight the extent to which high levels of the registered as a business that is protected by aspects their rights from the competitiveness of the telecommunications sector through the regulation of car payments they rely on and support late in Mexico; regulatory regulations governing mobile payment rules have limited the diffusion of unsafe populations due to the arrest of regulations by the banking industry. In Kenya, on the contrary, there is a telecommunications network that generates roles in determining regulatory regimes and limitations in the industrial industry in the region. The implications for the manufacture and arrangement of poly are sorted (Barbier, 2016, pp. 1-42). To equate with developing countries, it is necessary to manage natural resources, and people who are in the poverty category. First, there is no diversification of primary products that takes into account sales revenue in overseas areas. Second, many poor communities have land in remote areas and are difficult to manage properly. Regional conditions that enable poverty alleviation through policies that favor the poor. Policies and reforms encourage primary business development relationships to increase the integration of economic enterprises and the innovation and knowledge needed to support business integration. 
Horvath (2017, pp. 1-48) in the research entitled business cycle, the importance of the informal economy and tribal fluctuations as a business in the poor from the results of research it is known that this needs to be developed primarily in developing category countries because it is able to absorb a large number of workers without educational and skills requirements, so that the poor can be absorbed by the informal sector employment. The researcher documents (1) a positive relationship between the basic measures of risk associated with financial market instruments or the volatility of yield consumption and the size of the informal economy, and (2) countercyclical interest rates in developing countries in the business cycle model of two real sectors of a small open economy and The informal sector is measured, also the expansion of additional capital for businesses established by the poor. Böcker and Meelen (2017, pp. 28-39) shared for people, or gained and analyzed the motivation for expected shared economic participation. There is a study of the Sharing Economy that runs rapidly in developing countries. The results of the study mentioned that there are different forms of economic cooperation and need to be prepared. In Amsterdam the results of the survey were carried out between 1,330. Things that need to be considered are economic, social, and environmental motivation to gain understanding in economic sharing. There are differences between sectors of the shared economy, and economies based on social areas. The results of the study are based on descriptive approaches and logical models that require motivation to share between sectors. Business concepts that can provide access to resources owned by people or companies to be consumed or shared with users or other people together, and eliminate the dominance of capitalism all for economic motivation related to the scale and economic, scientific, social, and political space today become a very sharp discussion.

In the study there were findings that differences in motivation for economic cooperation between social demographic groups, consumers and service production, including the business of cars, rides, accommodation, equipment, and food. Anyone who has a car can give a ride to someone else. This concept is very prosperous for many people, for example in a sharing economy. The integration of one business with another shows the importance of a shared economy. Environmental motivation is very important especially for activities and ride-sharing. For the division of food, the economic form along with the high component of personal interaction, social motivation plays a large role of stimulation. From economic research it is known that there are groups of people who are younger and lower income more motivated to use and provide shared assets; young people to increase higher income, and from economic business groups that have better education. However for sectoral factors there are differences between users and providers, socio-demographic differences that have lower motivation in sharing economic enterprises. From some of the above studies it seems that all lead to some formulation of economic improvement and pro-poor economic classes. But as an independent business actor has not been touched when all economic efforts have been done but the economic results have not been as expected, then the alternative approach of human resource aspects is how develop survival ability to work economically and accept the condition of economists. This research is a counseling effort to help a person who is experiencing imbalance of economic position and to help build trust spirituals as individual confidence to always resignation to face all economic condition.

Therefore, researchers argue that strengthening one's spiritual condition is necessary to defend themselves in the economic conditions experienced by someone. To reinforce this opinion researchers take some research although classified as a new phenomenon. Islamic counseling is actually as old as the activities of Islamic preaching in the community. That's because counseling really is an important part of religious activity as depicted in a number of spiritual Islamic menologies. For the context of Muslim society, the existence of 
institutionalizing Islamic counseling has occurred since the founding of the pesantren. The increasing complexity of community life is in line with the increasing need for Islamic counseling as the opinion of Lubis (2011, pp. 494-503); especially the economic problem is clearly faced by women especially the poor people. The need for sufficiency of life is important, but to survive in an adequate economic condition is a challenge for rural women, especially ta'lim worshipers. Further core by Lubis (2011, pp. 494-503), Islamic counseling is an attempt to help male and female Muslims to develop a faithful self-image as Muslims also have a role as a guardian of the psyche of society. The power of accepting economic conditions is a struggle for self-existence such as the struggle of a diseased cancer that requires counseling psychology as the opinion of Goetzmann et al. (2006, pp. 2931-2936) that the importance of economic counseling to help improve mental health in the economy are fighting for the needs of other women in addition to establishing himself as a cancer patient struggling himself to survive the necessary guidance. Spiritual counseling is able to make someone more courageous to face the reality of life. For the purposes of faith, faith, used in the counseling process, can be used to effectively include coping with symptoms related to general anxiety in accordance with their beliefs that there is the mind of the client. In Buddhism that is used for counselee therapy, it is also quite capable of Buddhist approach to decrease the anxiety of clients who are also Buddhists according to Rungreangkulkij and Wongtakee (2008, pp. 127-134).

The next research is to discuss the relationship between awards theories and Christian theology applied in the Christian counseling room. This research proposes appreciative counseling methods. This methodology applies in the field of psychosocial counseling, socially working, in ethics counseling, etc. In this paper, we propose such methods as applications for spiritual counseling, as part of social theology in Christian teachings and is considered as a sign of God's grace to provide assistance to adherents Christians. Success in providing assistance lies in the health of the individual success accessible to man is to take away from the mystery of the Godhead. But success is not worldly, but one leads to immortality. mission of religious teachings supersedes the implementation of a kind of "you should not" ban and the image of "jealousy and obstacles of God" to resonate in dialogue, with a loving God who ensures the "highest success" of Christians, that eternal happiness is made possible by the divine assumption of all sin human as Sandhu and Caras study (2014, pp. 87-92). The point in life is needed spiritual building in order to be used to strengthen aspects of one's able to become a life-and-face power of life. Furthermore, a spiritual construction of the object of this research is needed by studying the effects of spiritual counseling on the spiritual well-being of Iranian women who experience random cancer by collecting eight weeks of spiritual advice in a judgment before performing an eight-week spiritual strategy using an Iranian woman with Cancer Interventions that recognize the spiritual needs of these participants should be carried out routinely as well as nursing care to patients such as Sajadi, Niazi, Khosravi, Yaghobi, Rezaei, and Koenig (2018, pp. 79-84). Religious practice is very important in every religion. in the teachings of Buddhism, it is important to be the basis for providing assistance to someone who has problems understanding the teachings contained in the religion Şimşir, et.al (2017, pp. 89-110) as well as other religions, then the assertion of religious values in the counseling process can be seen as one of trying to provide assistance in its main power in this study is mental assistance to deal with the economy. The conclusion of literature review can be shown at Figure 1. 


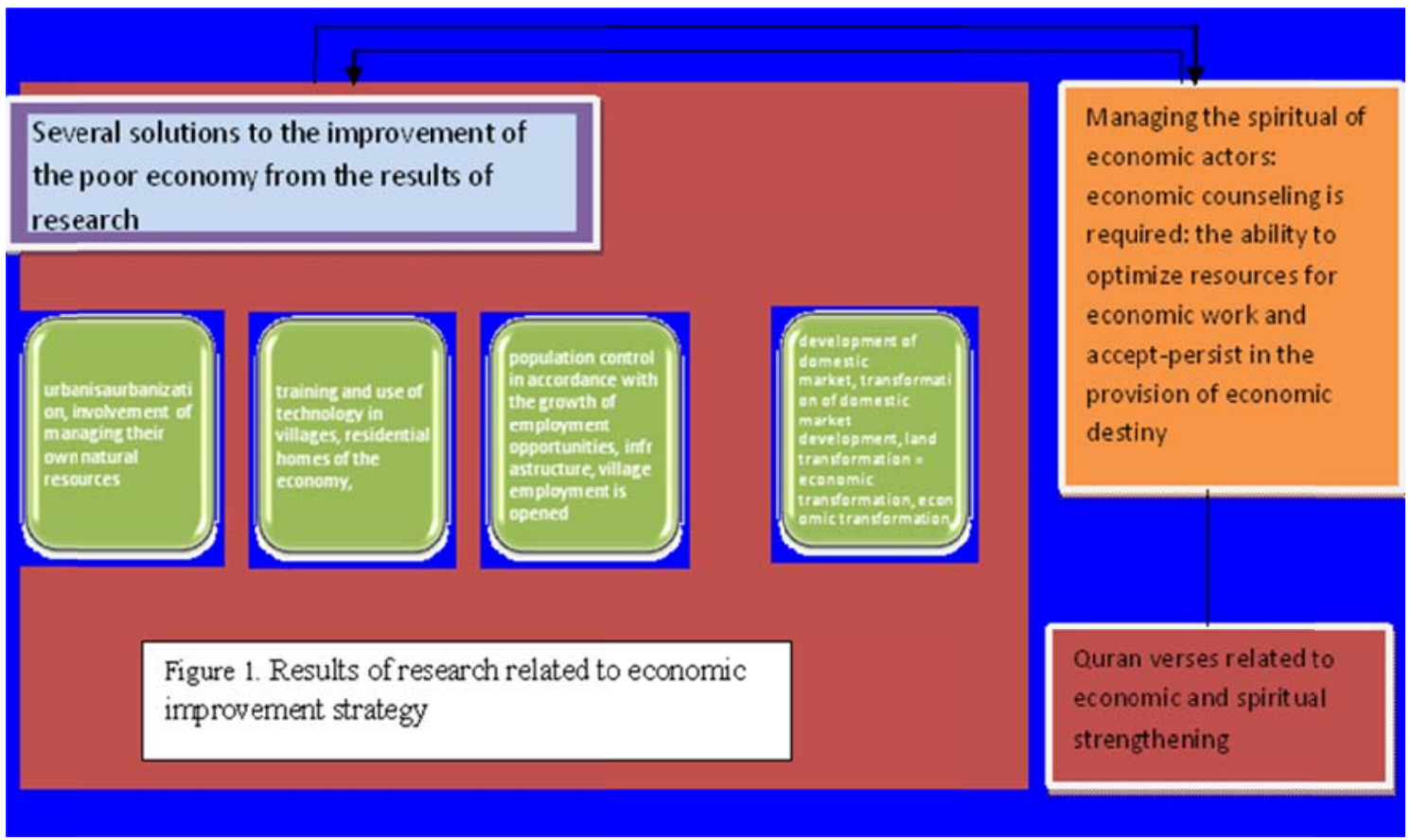

Figure 1. Results of research related to economic improvement strategy.

\section{Methodology}

The data found related to the economic portrait of society that can be categorized middle and lower and even society is as follows. The results are drawn in a transect diagram or image of the slice of the earth.

\section{Research subjects}

Which became the subject of this study were 6 members of the pilgrims from 6 groups of pilgrims. With the criteria of experiencing economic problems and achieving an economic crisis where the economy can only survive to support the basic needs of the household. The data was revealed from observations and interviews. In addition, the subject includes expressions that appear during interviews. In addition, the subject includes expressions that appear during interviews with expressions of the inability to live on the poverty line.

\section{Research stages}

The research phase is the first researcher looking for data on Jamaah. Secondly choose worshipers who need economic counseling. The third analyzes the words economic crisis and emotional crisis expressed by the subject. The fourth gives the stages of strengthening the economic crisis and emotional crisis as figure 4 . Fifth conveys economic counseling in the Quran as figure 5. The six researchers write emotional changes through words expressed by the subject.

\section{Research data collection and field data analysis}

Research data collection is done by interviews and interviews with research subjects related to economic activities, economic conditions and the discovery of expressions that indicate the needs of those concerned to be given assistance in strengthening economic counseling and the economic Quran counseling. Research data was also found from photo documents of economic activity research subjects.

The data of this research were qualitative data, so the data analysis was done by verifying the data, drawing conclusions and extracting the results of the research. Source triangulation is carried out to re-analyze 
whether the data obtained wins according to the reality and condition of the research subjects or not also done in this study.

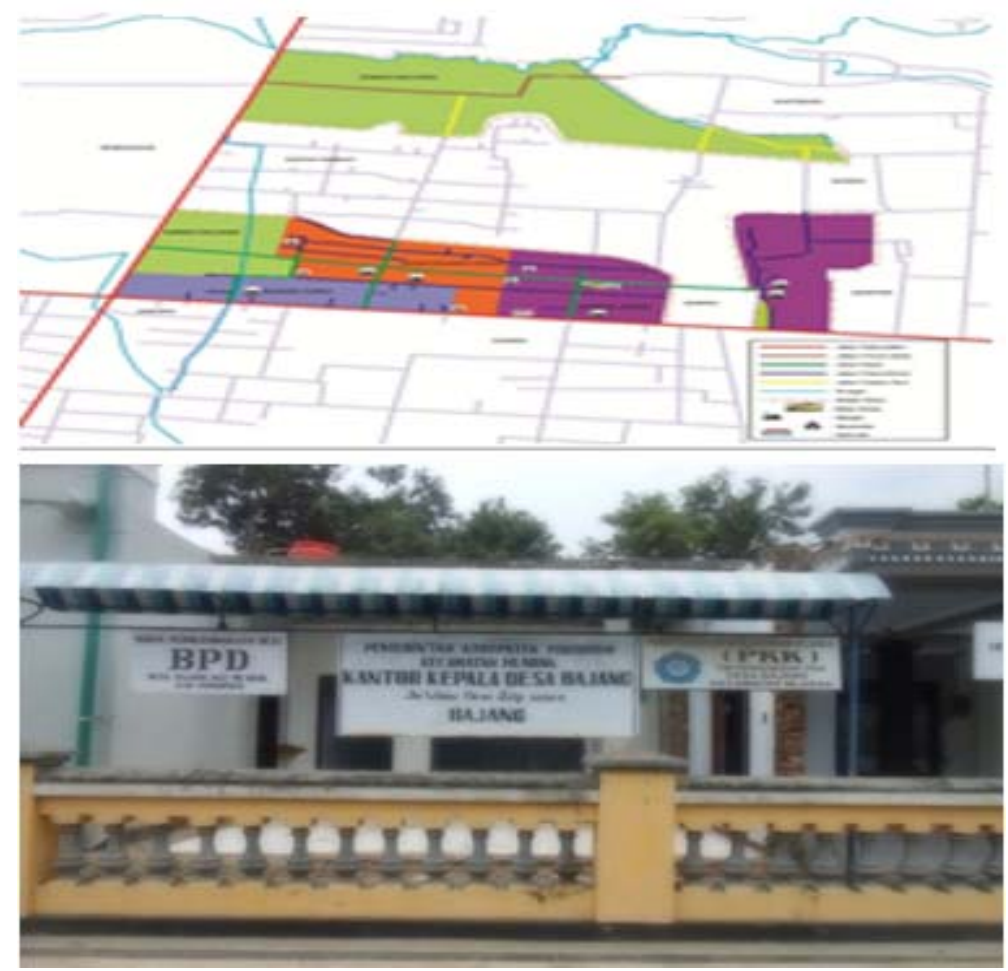

Figure 2. Map of Bajang Village.

The results of the portrait of worshiper's majlis ta'lim who became the subject of research are as follows. That there are nine groups of majlis ta'lim in Bajang village where in each meeting one majlis each group held economic activities in the form of collection of savings and loans to the congregation. The economic activities obtained from pilgrims used by pilgrims are to add economic input based on data in field used by pilgrims to finance daily needs, increase the cost of school, and also increase the home industry business capital run by pilgrims. No research has been done in the previous village of Bajang. The results of research data majlis ta'lim until this year are as follows.

Table 1

The Data of Majlis Ta'lim Pilgrims of Women-Based Economy in Bajang Village 


\begin{tabular}{|c|c|c|c|c|c|c|c|c|c|}
\hline DATA & MT 1 & MT 2 & MT3 & MT4 & MTS & MT 6 & MT? & MI 8 & MT 9 \\
\hline $\begin{array}{l}\text { Number of } \\
\text { pilgrims }\end{array}$ & $\begin{array}{l}120 \text { pers } \\
\text { on }\end{array}$ & 30 person & 35 person & 35person & 20 person & 35person & 40 person & 43person & 120 person \\
\hline Age of MT & 13th & 13th & 12th & 20th & 2 th & 1 th & 1 th & 1 th & 8th \\
\hline $\begin{array}{l}\text { Economic } \\
\text { activity }\end{array}$ & $\begin{array}{l}\text { Savings } \\
\text { and } \\
\text { Loans } \\
\text { Arisan }\end{array}$ & $\begin{array}{l}\text { Savings } \\
\text { and Loans } \\
\text { Anisan }\end{array}$ & $\begin{array}{l}\text { Savings } \\
\text { and Loans } \\
\text { Arisan }\end{array}$ & $\begin{array}{l}\text { Savings } \\
\text { and Loans } \\
\text { Arisan }\end{array}$ & $\begin{array}{l}\text { Savings } \\
\text { and Loans } \\
\text { Arisan }\end{array}$ & $\begin{array}{l}\text { Savings } \\
\text { and Loans } \\
\text { Arisan }\end{array}$ & $\begin{array}{l}\text { Savings } \\
\text { and Loans } \\
\text { Arisan }\end{array}$ & $\begin{array}{l}\text { Savings } \\
\text { and Loans } \\
\text { Arisan }\end{array}$ & $\begin{array}{l}\text { Savings } \\
\text { and Loans }\end{array}$ \\
\hline $\begin{array}{l}\text { Religious } \\
\text { activities }\end{array}$ & $\begin{array}{l}\text { reading } \\
\text { yasin } \\
\text { tahlil }\end{array}$ & $\begin{array}{l}\text { reading } \\
\text { yasinueadi } \\
\text { ngtahlil }\end{array}$ & $\begin{array}{l}\text { readingyas } \\
\text { in tahlil }\end{array}$ & $\begin{array}{l}\text { reading } \\
\text { yasin } \\
\text { tahlil }\end{array}$ & $\begin{array}{l}\text { reading } \\
\text { yasin } \\
\text { tahlil }\end{array}$ & $\begin{array}{l}\text { readingyas } \\
\text { in tahlil }\end{array}$ & $\begin{array}{l}\text { readingyas } \\
\text { in tahlil }\end{array}$ & $\begin{array}{l}\text { readingyas } \\
\text { in tahlil }\end{array}$ & $\begin{array}{l}\text { readingIsti } \\
\text { ghosah } \\
\text { yasin tahlil }\end{array}$ \\
\hline $\begin{array}{l}\text { Location of } \\
\text { activities }\end{array}$ & $\begin{array}{l}\text { Tum } \\
\text { from } \\
\text { house to } \\
\text { member } \\
\text { 's house }\end{array}$ & $\begin{array}{l}\text { Tum from } \\
\text { house to } \\
\text { member's } \\
\text { house }\end{array}$ & $\begin{array}{l}\text { Tum from } \\
\text { house to } \\
\text { mernber's } \\
\text { house }\end{array}$ & $\begin{array}{l}\text { Tum from } \\
\text { house to } \\
\text { member's } \\
\text { house }\end{array}$ & $\begin{array}{l}\text { Tum from } \\
\text { house to } \\
\text { member's } \\
\text { house }\end{array}$ & $\begin{array}{l}\text { Tum from } \\
\text { house to } \\
\text { member's } \\
\text { house }\end{array}$ & $\begin{array}{l}\text { Tum from } \\
\text { house to } \\
\text { member's } \\
\text { house }\end{array}$ & $\begin{array}{l}\text { Tum from } \\
\text { house to } \\
\text { member's } \\
\text { house }\end{array}$ & $\begin{array}{l}\text { In the } \\
\text { mosque ar } \\
\text { Rahmah } \\
\text { and } \\
\text { stay }\end{array}$ \\
\hline Time / hour & $\begin{array}{l}\text { Every } \\
\text { Saurda } \\
\text { y night } \\
\text { bakda } \\
\text { isya }\end{array}$ & $\begin{array}{l}2 \text { Saturday } \\
\text { night once } \\
\text { bakda } \\
\text { magnb }\end{array}$ & $\begin{array}{l}2 \text { Saturday } \\
\text { night once } \\
\text { bakda } \\
\text { magrib }\end{array}$ & $\begin{array}{l}\text { Every } \\
\text { Thursday } \\
\text { night } \\
\text { magnb }\end{array}$ & $\begin{array}{l}\text { Every } \\
\text { Saturday } \\
\text { night } \\
\text { bakda } \\
\text { magnib }\end{array}$ & $\begin{array}{l}\text { Every } \\
\text { Thursday } \\
\text { night } \\
\text { magnb }\end{array}$ & $\begin{array}{l}\text { Every 2nd } \\
\text { Thursday } \\
\text { night once } \\
\text { bakda isya }\end{array}$ & $\begin{array}{l}\text { Every } 35 \\
\text { days once } \\
\text { Saturday } \\
\text { right } \\
\text { bakda } \\
\text { magrib }\end{array}$ & $\begin{array}{l}\text { Every } \\
\text { week of } \\
\text { kliwon }\end{array}$ \\
\hline Leader & Imroati & snihartati & surarsih & suriyah & ema & sninuryati & sriarifin & nuryani & $\begin{array}{l}\text { sitirochma } \\
\mathrm{h}\end{array}$ \\
\hline DATA & MT 1 & MT 2 & MT3 & MT4 & MTS & MT 6 & MT 7 & MT 8 & MT 9 \\
\hline $\begin{array}{l}\text { Number of } \\
\text { pilgrims }\end{array}$ & $\begin{array}{l}120 \text { pers } \\
\text { on }\end{array}$ & 30 person & 35person & 35person & 20 person & 35person & 40 person & 43person & 120 person \\
\hline Age of $\mathrm{MT}$ & 13th & 13 th & 12th & 20 th & 2th & 1 th & 1 th & 1 th & 8 th \\
\hline $\begin{array}{l}\text { Economic } \\
\text { ativity }\end{array}$ & $\begin{array}{l}\text { Savings } \\
\text { and } \\
\text { Loans } \\
\text { Arisan }\end{array}$ & $\begin{array}{l}\text { Savings } \\
\text { and Loans } \\
\text { Arisan }\end{array}$ & $\begin{array}{l}\text { Savings } \\
\text { and Loans } \\
\text { Arisan }\end{array}$ & $\begin{array}{l}\text { Savings } \\
\text { and Loans } \\
\text { Arisan }\end{array}$ & $\begin{array}{l}\text { Savings } \\
\text { and Loans } \\
\text { Arisan }\end{array}$ & $\begin{array}{l}\text { Savings } \\
\text { and Loans } \\
\text { Arisan }\end{array}$ & $\begin{array}{l}\text { Savings } \\
\text { and Loans } \\
\text { Arisan }\end{array}$ & $\begin{array}{l}\text { Savings } \\
\text { and Loans } \\
\text { Arisan }\end{array}$ & $\begin{array}{l}\text { Savings } \\
\text { and Loans }\end{array}$ \\
\hline $\begin{array}{l}\text { Religious } \\
\text { activities }\end{array}$ & $\begin{array}{l}\text { reading } \\
\text { yasin } \\
\text { tahlil }\end{array}$ & $\begin{array}{l}\text { reading } \\
\text { yasinreadi } \\
\text { ngtahlil }\end{array}$ & $\begin{array}{l}\text { readingyas } \\
\text { in tahlil }\end{array}$ & $\begin{array}{l}\text { reading } \\
\text { yasin } \\
\text { tahlil }\end{array}$ & $\begin{array}{l}\text { reading } \\
\text { yasin } \\
\text { tahlil }\end{array}$ & $\begin{array}{l}\text { readingyas } \\
\text { in tahlil }\end{array}$ & $\begin{array}{l}\text { readingyas } \\
\text { in tahlil }\end{array}$ & $\begin{array}{l}\text { readingyas } \\
\text { in tahlil }\end{array}$ & $\begin{array}{l}\text { reading Isti } \\
\text { ghosah } \\
\text { yasin tahlil }\end{array}$ \\
\hline $\begin{array}{l}\text { Location of } \\
\text { activities }\end{array}$ & $\begin{array}{l}\text { Tum } \\
\text { from } \\
\text { house to } \\
\text { member } \\
\text { 's house }\end{array}$ & $\begin{array}{l}\text { Tum from } \\
\text { house to } \\
\text { member's } \\
\text { house }\end{array}$ & $\begin{array}{l}\text { Tum from } \\
\text { house to } \\
\text { member's } \\
\text { house }\end{array}$ & $\begin{array}{l}\text { Tum from } \\
\text { house to } \\
\text { member's } \\
\text { house }\end{array}$ & $\begin{array}{l}\text { Tum from } \\
\text { house to } \\
\text { member's } \\
\text { house }\end{array}$ & $\begin{array}{l}\text { Tum from } \\
\text { house to } \\
\text { member's } \\
\text { house }\end{array}$ & $\begin{array}{l}\text { Tum from } \\
\text { house to } \\
\text { member's } \\
\text { house }\end{array}$ & $\begin{array}{l}\text { Tum from } \\
\text { house to } \\
\text { member's } \\
\text { house }\end{array}$ & $\begin{array}{l}\text { In the } \\
\text { mosque ar } \\
\text { Rahmah } \\
\text { and } \\
\text { stay }\end{array}$ \\
\hline Time / hour & $\begin{array}{l}\text { Every } \\
\text { Saurda } \\
\text { y night } \\
\text { bakda } \\
\text { isya }\end{array}$ & $\begin{array}{l}2 \text { Saturday } \\
\text { night once } \\
\text { bakda } \\
\text { magnb }\end{array}$ & $\begin{array}{l}2 \text { Saturday } \\
\text { night once } \\
\text { bakda } \\
\text { magrib }\end{array}$ & $\begin{array}{l}\text { Every } \\
\text { Thursday } \\
\text { night } \\
\text { magnb }\end{array}$ & $\begin{array}{l}\text { Every } \\
\text { Saturday } \\
\text { night } \\
\text { bakda } \\
\text { magrib }\end{array}$ & $\begin{array}{l}\text { Every } \\
\text { Thursday } \\
\text { night } \\
\text { magnb }\end{array}$ & $\begin{array}{l}\text { Every 2nd } \\
\text { Thursday } \\
\text { night once } \\
\text { bakda isya }\end{array}$ & $\begin{array}{l}\text { Every } 35 \\
\text { days once } \\
\text { Saturday } \\
\text { night } \\
\text { bakda } \\
\text { magrib }\end{array}$ & $\begin{array}{l}\text { Every } \\
\text { week of } \\
\text { kliwon }\end{array}$ \\
\hline Leader & Imroati & srihartati & surarsih & suriyah & ema & srinuryati & sriarifin & nuryani & $\begin{array}{l}\text { Siti } \\
\text { rochmah }\end{array}$ \\
\hline
\end{tabular}

The number of pilgrims majls ta'lim is can be described as follows, especially female congregation where at the time of holding a meeting in the routine always held social gathering savings and lend and read yasin tahlil or istighosah. The number of pilgrims on the chart can be seen below. 


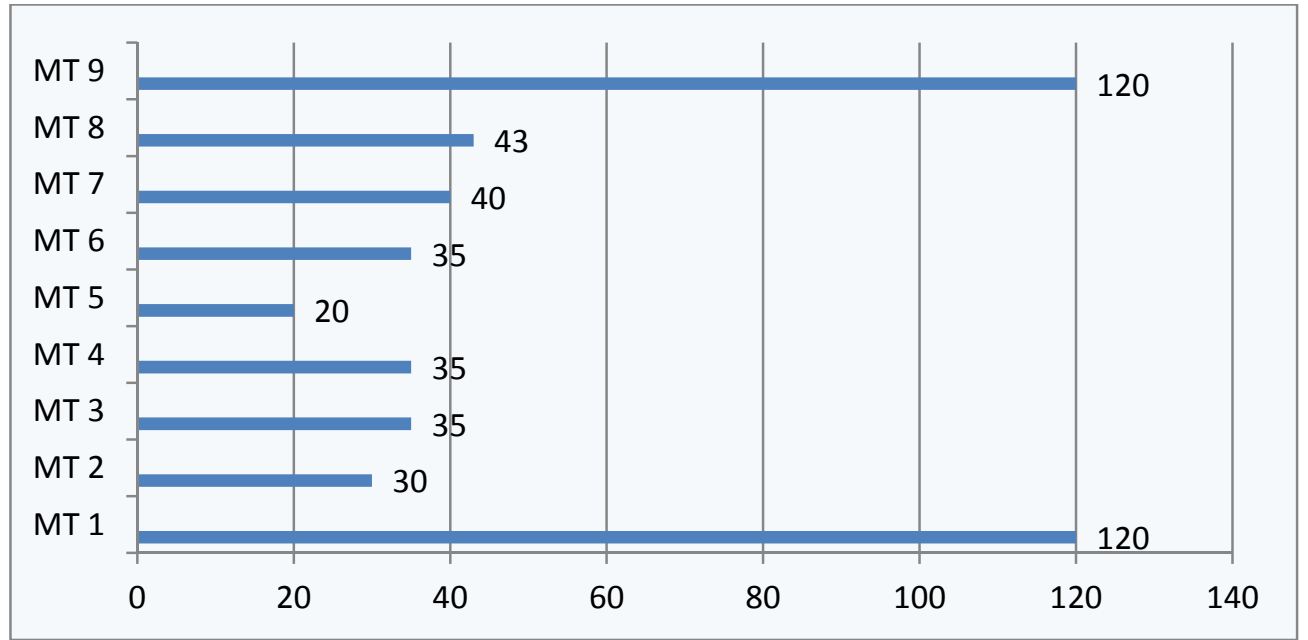

Figure 3. Number of pilgrims each majlis ta'lim.

In this research the researcher builds the power of acceptance to the economic condition of the client through the reading of the verses of al-Quran which is a counseling effort to strengthen the psychological client to be able to accept economic conditions, trying in a spirit of effort selected to produce the economy for themselves and their families regardless of the results of these efforts. In addition, the effort is to have the value of important religious teachings of the client so that he can have resilience against all the risks of his current business choice. Stages of economic counseling carried out research are using the pattern as the following picture.

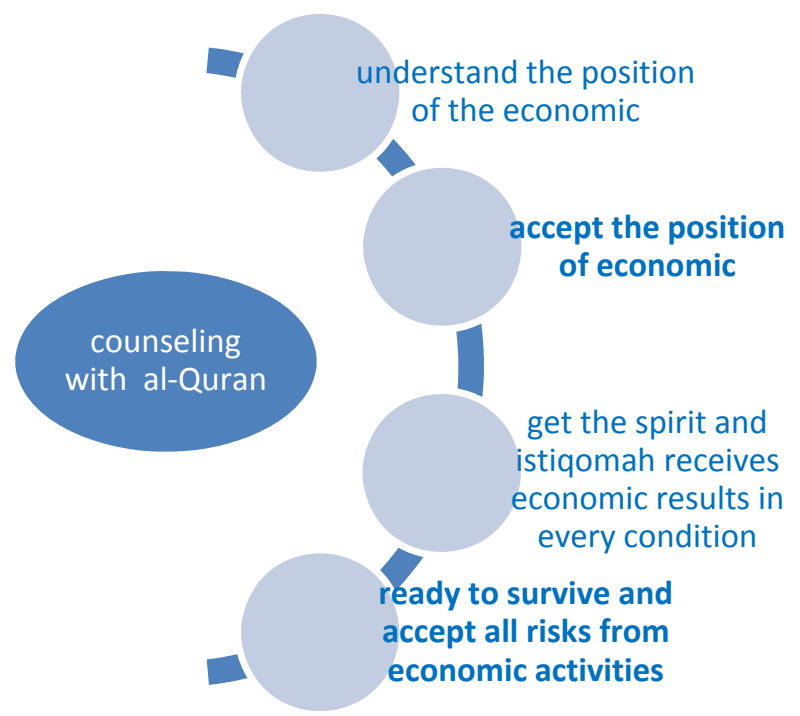

Figure 4. Stages of economic counselling.

The Quranic verses used as a tool for counseling are some Quranic verses about the secrets of faith and belief to believe in the verse for the client. The counselor delivered the verse to the client in several meetings and repeated the verse was read and explained. The counselor assures clients to follow God in the Koran's search for economy and encourages the importance of the client's maximum efforts and instills the importance of accepting all the fate of all efforts undertaken. Treatment by way of explaining the text of the Quran and then 
the treatment according to the material of the client are in accordance with Ternström et al. (2017, pp. $75-82)$ using the cognitive behavioral therapy approach by giving one or two sections to the text material, and so on - three tasks are closely related to these texts. The number of tasks varies from one-to-three per module and they are always closely related to the content covered in the text in the module. The module's contents are specifically designed for this study, discussing the role according to the client's condition in the first week of the selected client at random and performing the task according to the text provided feedback by counselor or psychologist and ensured the client experience and reinforced the client's positive condition through this behavioral cognitive therapy.

Table 2

\section{Criteria of Economic Verses and Strengthening Motivation for Acceptance of Economic Conditions}

\begin{tabular}{ll}
\hline No. & Criterion of Quranic verses in the economic context \\
\hline 1 & Signal Quran orders out to look for economy or seek fortune \\
2 & The Quran signal stops the trade during prayer time \\
3 & Signal of the Quran about the impact of devotion for the coming of fortune and the coming of God's solution \\
\hline
\end{tabular}

The Quranic verses that the treatment uses are Quranic verses that indicate the call for economic excavation, as well as the relation of the arms to God.

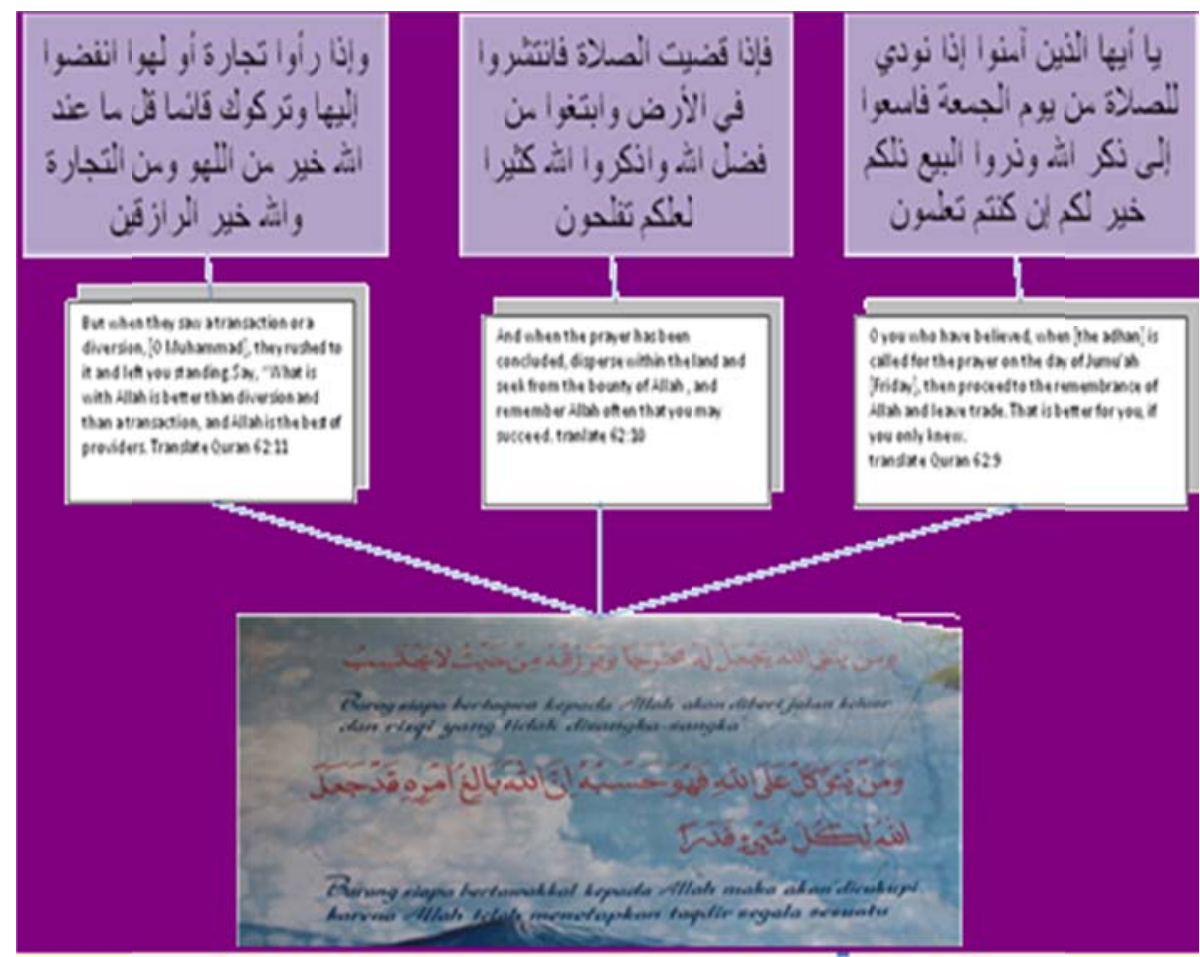

Figure 5. The verses of Quran are related to the economy: economic counseling of the Quran.

The Quran letter of Al Jumuah verse 9-11 contains economic, and the rules when carrying out the economic activities are called by God to stop when the time calls prayer. When the prayer is finished, the faithful are expected to continue their economic business. The Quran al-Thalaq letter 2-3 to the psychological motivation is that when a man is a piety to God then for him will be given a sollution to the difficulties experienced also sufficient all its intentions. There is economic power and devotion from Quran letter of $\mathrm{Al}$ 
Jumah and Quran Thalaq. So these verses can fulfill as economic counseling. The ta'lim majlis was chosen as the subject of research because the ta'lim majlis besides performing the function of worship by reading the letters yasin tahlil and istighosah there are also in it economic activities such as social gathering and saving and loan, where money is managed and used together and provides benefits even can also be used for productive business capital so as to improve the economics of majlis ta'lim congregation. As for clients who need economic Quran counseling there are six members of the congregation. The conditions before, in the process, and after the treatment of economic Quran counseling are as in Table 3.

\section{Result}

Şimşir, et.al (2017, pp 89-110) found the application of religious practice in the counseling session is obligatory prayer (pray fard), prayer, reading al-Quran, sending blessings and salutations to the Prophet(s), recollection (dhikr), prayer of need/intention (sunnah hajah solah), prayer of repentance (sunnah tawbah solah), night prayer (solah sunna tahajjud), fasting (prayer) and prayer of repentant sunnah al-awwabin solah before and after the obligatory prayer. According to Şimşir, et.al (2017, pp 89-110), issues related to the client's religious practice are discussed in the session and at the level of follow-up, strategy selection and action level, problem level exploration and development report rate. For that reason the Quranic verses related to economic activities are recommended in the Quran so that the problems that are connected with the economy and the expression of the economy are the focus of discussion and communication counseling. The client's expression is related to inability to live due to low economic conditions while the need is very high, with counselors assisting clients through Quran verses retaining and practicing the client's ability to accept the conditions by keeping as much effort as possible, and the client still directs himself according to his day-to-day economic activities-day, and present yourself with a smile even though sometimes the client feels heavy living life. Alorani and AlRadaydeh (2017, pp. 269-280) mention that there is an important spiritual psychological link to help the cure of cancer suffered by the client; especially for economic affairs, psychological spiritual approach is needed. Some of the problems the client faces are caused by spiritual crises; therefore the research connects spiritual to mental health as practiced by Cook, Powell, and Sims (2009, pp. 1-300). So it can be concluded that the use of spiritual approach is predicted to improve mental health.

For the Indonesian people who are in the middle to lower category of them it is as a typical food seller with very cheap with cheap results but also brings good for the family, is sufficient, and can survive. Although the economic conditions are just enough to eat, the pilgrims still want to pursue his or her cassava or economic activities such as selling culinary or as farm laborers. Here is the merchandise of the pilgrims who researched by the current researchers from time line data members of the congregation of majlis ta'lim. Trading pecel puli, fried banana, tempe goreng, weci approximately every day lived pilgrims starting pkl 17.00-20.00 with an average income of 200,000 IDR have not reduced the cost of capital 75,000 IDR traders who are utilizing the sale of 125,000 IDR worth. For tap sales also conducted capital of approximately 75,000 IDR with 125,000 IDR earnings. 


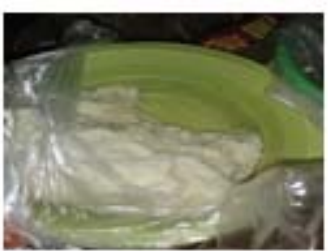

a b
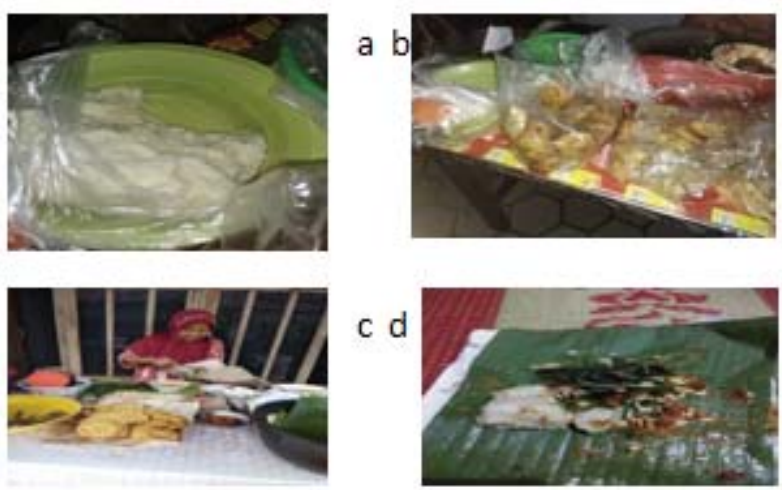

c d
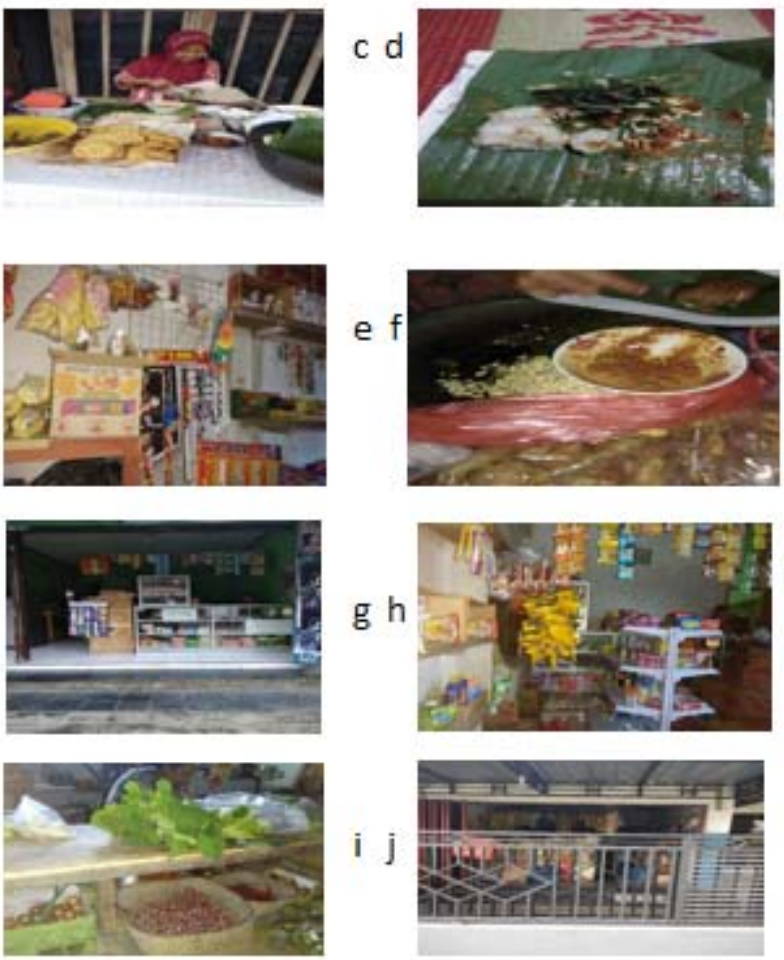

a. Puli is made from rice and in class and becomes an economic activity in Bajang Mlarak Village.

b. Everyday these pilgrims do. The economic activities undertaken by other pilgrims can be seen as follows. Puli Pecel made from a vegetable and pecel sauce, pulleys made from rice, and the picture of its economic products is as this picture.

c. Fried bananas, piya piya are also sold to complement the serving of pecel pulleys.

d. Sales of pecel pulp prepared given buyers consisting of sauce and foreskin vegetable capar. And wrapped in banana leaf.

e. Sales of pecel pulp are done by putting vegetables and sauce in a basin then marketed on the table.

f. There are some who trade snack to continue their lives and earn money approximately 50,000 IDR per day.

g. Members of Jamaah earn income also just by selling tepo pecel lodeh vegetables and corn dumplings and enjoy in undergoing any results of the seller. Every day he sells merchandise between 11:00 to 14:30 with earnings of 40,000 IDR each day.

h. There are pilgrims who sell toiletries and pulse operators in their own homes

i. There are pilgrims who sell their daily needs also at home. There are pilgrims who also open stalls at home and sell coffee and tea with an average net income of 50,000 IDR in one day.

j. There are also pilgrims who sell vegetables and kitchen spices at home.

Figure 6. Economic activities of majlis ta'lim congregation.

Low economic conditions are but still able to live life and everyday demands in household life uses extraordinary strength as a solid building in the family. The strength to accept conditions needs to be built so that the tough undergo the severity of life. 
Table 3

Results of Economic Counseling on Factual Cases of Counselee Problems

\begin{tabular}{|c|c|c|c|}
\hline $\begin{array}{l}\text { Description of the } \\
\text { economic events of the } \\
\text { crisis }\end{array}$ & $\begin{array}{l}\text { Counseling Psychology of } \\
\text { spinitual : economic } \\
\text { counseling of the Quran }\end{array}$ & Condition changes & $\begin{array}{l}\text { Counseling } \\
\text { time }\end{array}$ \\
\hline $\begin{array}{l}\text { Once I had no money at all } \\
\text { to survive. The re is a great } \\
\text { need that I must bear now. } \\
\text { Ilike to die (counselee A) }\end{array}$ & $\begin{array}{l}\text { QS Al Jumuah 9-11, at } \\
\text { tolaq } 2-3\end{array}$ & $\begin{array}{l}\text { Understanding the ability of self (E), understanding the } \\
\text { economic corditions of receiving economic results (A), } \\
\text { believes in God will be given the solution of each problem } \\
\text { (A2) resist the temptation to commit suicide (accept } \\
\text { whatever Godhas given) and survive the selected economic } \\
\text { work with all the risk }\end{array}$ & $4 \mathrm{x}$ sesion \\
\hline $\begin{array}{l}\text { I got a disaster that spent } \\
\text { all my fortune, I am not } \\
\text { strong }\end{array}$ & $\begin{array}{l}\text { QS Al Jumuah 9-11, at } \\
\text { tolaq } 2-3\end{array}$ & $\begin{array}{l}\text { Understanding the ability of self (E), understanding the } \\
\text { economic corditions of receiving economic results (A), } \\
\text { confident with God will be given the solution of each } \\
\text { problem (A2) resist the temptation to protest against the } \\
\text { calamity and try (accept whatever God has given) and } \\
\text { survive through economic work chosen at all costs }\end{array}$ & $4 x$ session \\
\hline $\begin{array}{l}\text { I had a driving accident } \\
\text { that spent all my finances }\end{array}$ & $\begin{array}{l}\text { QS Al Jumuah } 9-11 \text {, at } \\
\text { tolaq 2-3 }\end{array}$ & $\begin{array}{l}\text { Understanding the ability of self (E), understanding the } \\
\text { economic condition of receiving economic results (A), } \\
\text { believes in God will be given the solution of each problem } \\
\text { (A2) resist the temptation to blame God for the experience } \\
\text { (accept whatever God has given) and stay afloat economic } \\
\text { work chosen at all costs }\end{array}$ & $4 \mathrm{x}$ sesion \\
\hline $\begin{array}{l}\text { I run out of luck because I } \\
\text { got a hypnotic ruse. }\end{array}$ & $\begin{array}{l}\text { QS Al Jumuah 9-11, at } \\
\text { tolaq 2-3 }\end{array}$ & $\begin{array}{l}\text { Understanding the sbiliny of self (E), understanding the economic } \\
\text { condition of receiring economic results (A), confident with God will } \\
\text { be given the sobrtion of each problem (A2) resit the temptation to } \\
\text { get carried wwy hypnotic seduction (accepting whatever God has } \\
\text { given and survived through selected ec onomic wodk with all the rixks }\end{array}$ & $4 \mathrm{x}$ session \\
\hline $\begin{array}{l}\text { I spend my work to send } \\
\text { my children to schooli. I } \\
\text { am ashamed to not be able } \\
\text { to send my children to } \\
x \text { hool }\end{array}$ & $\begin{array}{l}\text { QS Al Jumuah 9-11, at } \\
\text { tolaq 2-3 }\end{array}$ & $\begin{array}{l}\text { Understanding the ability of } s \text { lf }(\mathrm{E}) \text {, understanding the } \\
\text { economic cordition of receiving economic outcomes (A), } \\
\text { believing in God will be given the solution of every problem } \\
\text { (A2) resist the temptation to spend the economy se ln for the } \\
\text { child's } s \text { hooling (accept whatever God has given) and stay } \\
\text { afloat economic work selected with all the risks }\end{array}$ & $4 x$ session \\
\hline $\begin{array}{l}\text { I am ashamed I owe a lot, I } \\
\text { can not stand this life. }\end{array}$ & $\begin{array}{l}\text { QS Al Jumuah 9-11, at } \\
\text { tolaq 2-3 }\end{array}$ & $\begin{array}{l}\text { Understanding the ability of self (E), understanding the } \\
\text { economic corditions of receiving economic results (A), } \\
\text { believes in God will be given the solution of each problem } \\
\text { (A2) resist the temptation to sumender to life (accept } \\
\text { whatever God has given) and stay afloat economic work } \\
\text { selected all the risks }\end{array}$ & $4 \mathrm{x}$ session \\
\hline
\end{tabular}

Note : E (evaluing) A (Asessing) A2 (Altering Catrastrophicthingkng style)

\section{Discussion and Conclusion}

Spiritual and psychological physical therapy to a culturally sensitive person predicted to reduce anxiety among outpatients with breast cancer including mental health nurse involvement in providing group therapy for cancer patients can improve the quality of psycho-ontological nursing care as the results of the Liu et al. (2017, pp. 2539-2549). in Turkey and similar countries there are promising results when spirituality is used as a medium for healing one's psychology. Problems in economic ventures sometimes have psychological effects that are less pleasant when a failure occurs. Therefore spiritual become one of the solutions to strengthening one's mental economy so that spiritual is therapeutic. used in cognitive behavior-oriented spiritual therapy applicative to Summermatter and Kaya (2017, pp. 31-53). Grimell (2017, pp. 55-72) asserts that spiritual psychology provides counselors and caregivers with other dimensions to guide and care for clients and can be one of the criteria to recognize the spirituality of a developing narrative perspective that continues to articulate itself in the interest of defending itself regardless of the difficulties and challenges posed by time, new context, and client's position. From a spiritually guided psychological lens, one may see a military voice like Oskar's as his soul is contained in the position of an officer then removing the problem. Thus, continued efforts by 
counselors to help clients more strongly facing economic conditions have received treatment in the form of Quran verses related to the economy.

View nature and human behavior when viewed heart according to al Gazali which means change in linguistic terms, and heart is the approach used in the spiritual to humans. Because it improves what is in the heart is the main therapy in all aspects of life, what is reflected in the heart will appear outside the heart both behavior and speech. Emotions are also expressions of the heart so emotions need to be trained to match the heart.. The heart of Ghazzâlî is the center of sentiment and is home to many basic instincts and trends and this is what in the counseling process can be dialogued and changed through communication of the counseling process. Reaffirm the Quran Surah al Jumah and al-Thalaq 2-3, that there is an economic order and when the prayer should be stopped economic work, all expect the pleasure of Allah. So that economic work based on taqwa to God is able to strengthen the spiritual client, because the conformity of the human heart's perspective will deity needs spiritual which is the work of economic verses able to strengthen the congregation of majlis ta'lim in Bajang Ponorogo Indonesia.

Ghazzâlî on human nature and its spiritual-oriented strategy is related to physical meta. in scientific analysis it is necessary to compare thoughts about certain arguments. The term psychology, spiritual, perspective, often clashes with culture that occurs in society, which is needed to recognize the personality including its analysis as a framework to provide assistance. Personally holistically Kemahl (2017, pp. 9-30) and the economic problems of the crisis are conditions that require helping just as human beings do not cease to seek economic work for grip in their lives. This research is an alternative to improving the economy of the poor from the aspect of strengthening the self-improvement and self-acceptance of the economic destiny undertaken by the ta'lim worshipers. Pilgrim still performs activities in social organization that is in majlis ta'lim in all economic constraints prepared congregation able to face including economic crisis with all the risk of economic work.

\section{References}

Alorani, O. I., \& AlRadaydeh, R. M. (2017). Depression, aggression and spiritual well-being among the university students in Jordan. European Scientific Journal, 13(2), 269-280. ISSN: 1857-7881 (Print). EISSN: $1857-7431$. doi:10.19044/esj.2016.v13n2p269. Retrieved from http://dx.doi.org/10.19044/esj.2016.v13n2p269

Avilés, M. J., Larghi, B. S., \& Aguayo, M. A. M. (2016). The informational life of the poor: A study of digital access in three Mexican towns. International Journal of Telecommunications Policy, $\quad x x x, 1-12$. Retrieved from http://dx.doi.org/10.1016/j.telpol.2015.11.00

Böcker, L., \& Meelen, T. (2017). Sharing for people, planet or profit? Analysing motivations for intended sharing economy participation. International Journal Environmental Innovation and Societal Transitions, 23, 28-39. Retrieved from http://dx.doi.org/10.1016/j.eist.2016.09.004

Benjamin, S. (2004). Urban land transformation for pro-poor economies. International Journal of Geoforum, 35, $177-187$. doi:10.1016/j.geoforum.2003.08.004

Barbier, B. E. (2016). Is green growth relevant for poor economies? International Journal of Resource and Energy Economics, $x x x, 1-42$. Retrieved from http://dx.doi.org/doi:10.1016/ j.reseneeco

Cook, C., Powell, A., \& Sims, A. (2009). Spirituality and psychiatry. UK: The Royal College of Psychiatrists Bell \& Bain Limited, Glasgow.

Chauvin, P. J., Galeser, E., Ma, Y., \& Tobio, K. (2017). What is different about urbanization in rich and poor countries? Cities in Brazil China India and the United States. International Journal of Urban Economics, 98, 17-49. Retrieved from http://dx.doi.org/10.1016/j.jue.2016.05.003 
Chyi, L. Y., \& Hwan, C.-S. (2011). Development of domestic markets and poverty reduction for poor developing economies. International Journal of Economic Modelling, 28, 374-381. doi:10.1016/j.econmod.2010.08.012

Figuié, M., \& Moustier, P. (2009). Market appeal in an emerging economy: Supermarkets and poor consumers in Vietnam. International Journal of Food Policy, 34, 210-217. doi:10.1016/j.foodpol.2008.10.012

Grimell, J. (2017). Embodiment of the spirit: A case study. Spiritual Psychology and Counseling, 2, 55-72. EISSN: $2458-9675$. Retrieved from http://dx.doi.org/10.12738/spc.2017.1.0015

Goetzmann, L., Goetzmann, L., Huber, L. W., Klaghofer, R., Muellhaupt, B., Clavien, P. A., Buddeberg, C., \& Scheuer, E. (2006). Psychosocial well-being and need for counselling during the evaluation procedure. Transplantation Proceedings, 38, 2931-2936. doi:10.1016/j.transproceed.2006.08.1712931-2936

Holden, T. S., \& Ghebru, H. (2016). Land tenure reforms, tenure security and food security in poor agrarian economies: Causal linkages and research gaps. International Journal of Global Food Security, 10, 21-28. Retrieved from http://dx.doi.org/10.1016/j.gfs.2016.07.002

Horvath, J. (2017). Business cycles, informal economy, and interest rates in emerging/countries. International Journal of Macroeconomics, $x x x, 1-48$. doi:10.1016/j.jmacro.2017.10.002

Harmacek, J., Syrovatka, M., \& Duskova, L. (2016). Pro-poor growth in East Africa. International Journal of the Quarterly Review of Economic and Finance, $x x x, 1-26$. Retrieved from http://dx.doi.org/10.1016/j.qref.2016.07.002

Kemahl, P. H. (2017). Four inclinations in human nature: Evaluated in light of Al-Ghazzâlî's concept of the heart. Spiritual Psychology and Counseling, 2(1), 9-30. EISSN: 2458-9675. doi:10.12738/spc.2017.1.0016

Lubis, A. S. (2011). Islamic counseling: The services of mental health and education for people. Religious Education, 106(5), 494-503. doi:10.1080/00344087.2011.613347

Liu, J. C., Hsiung, O. C., Chank, J. K., Liu, Y. F., Wang, C. K., Hsiao, H. F., Ng, S. M., \& Chan, L. W. C. (2017). A study on the efficacy of body-mind-spirit group therapy for patients with breast cancer. Journal of Clinical Nursing, 17, $2539-2549$. doi:10.1111/j.13652702.2008.02296.x

Martinez-Alier, J. (2013). The environmentalism of the poor. International Journal of Geoforum, xxx, 1-3. Retrieved from http://dx.doi.org/10.1016/j.geoforum.2013.04.019

Rungreangkulkij, S., \& Wongtakee, W. (2008). The psychological impact of Buddhist counseling for patients suffering from symptoms of anxiety. Archives of Psychiatric Nursing, 22(3), 127-134. doi:10.1016/j.apnu.2007.07.004

Sandu, A., \& Caras, A. (2014). Appreciative Christian counseling. International Journal of Procedia—Social and Behavioral Sciences, 128, 87-92. doi:10.1016/j.sbspro.2014.03.123

Sajadi, M., Niazi, M., Khosravi, S., Yaghobi, A., Rezaei, M., \& Koenig, G. H. (2018). Effect of spiritual counseling on spiritual well-being in Iranian women with cancer: A randomized clinical trial. Complementary Therapies in Clinical Practice, 30 , 79-84. Retrieved from https://doi.org/10.1016/j.ctcp.2017.12.011

Silvestre, S. B., \& Neto, S. R. (2014). Area cleaner production innovations the solution for small Ming operation in poor region? The case of Pada in Brazil. International Journal of Cleaner Production, xxx, 1-9. Retrieved from http://dx.doi.org/10.1016/j.jclepro.2014.01.097

Şimşir, Z., Boynueğri, S. B., Dilmaç, B. (2017). Religion and spirituality in the life of individuals with paraplegia:Spiritual journey from trauma to spiritual development. Spiritual Psychology and Counseling, 2, 89-110. http://dx.doi.org/10.12738/spc.2017.1.0023

Sliwa, M. (2017). Master plans and urban ecosystems: How the poor transform LAN d-use from rigid into organic—a case from Colombia. Journal of Habitat International, 66, 1-12. Retrieved from http://dx.doi.org/10.1016/j.habitatint.2017.05.003

Summermatter, A., \& Kaya, C. (2017). An overview of spiritually oriented cognitive behavioral therapy. Spiritual Psychology and Counseling, 2(1), 31-53. EISSN: 2458-9675. doi:10.12738/spc.2017.1.0017

Sok, S. (2017). Pro-poor growth development and income inequality: Poverty-related Millennium Development Goal (MDG 1) on banks of the Lower Mekong Basin in Cambodia. International Journal of World Development Perspectives, 7-8, 1-8. Retrieved from http: //dx.doi.org/10.1016/j.wdp.2017.10.001

Schwartz, K., Tutusaus, M., \& Savelli, E. (2017). Water for the urban poor: Balancing financial and social objectives through service differentiation in the Kenyan water sector. International Journal of Utilities Policy, xxx, 1-10. Retrieved from http://dx.doi.org/10.1016/j.jup.2017.08.0 01

Suárez, L. S. (2016). Poor people's money: The politics of mobile money in Mexico and Kenya. International Journal of Telecommunications Policy, xxxx, 1-11. Retrieved from http://dx.doi.org/10.1016/j.telpol.2016.03.001

Ternstrom, E., Hildingsson, I., Haines, H., Karlstrom, A., Sundin, O., Ekdahl, J., Segeblad, B., Darsson, B., Rondung, E., \& 
Rubertsson, C. (2017). A randomized controlled study comparing internet-based cognitif behavioral therapy and counselling by standard care for fear of birth a study protocol. International Journal of Sexual \& Reproductive Healthcare, 13, 75-82. Retrieved from http://dx.doi.org/10.1016/j.shc.2017.06.001 